\title{
The Effect of Additives Interaction on the Miscibility and Crystal Structure of Two Immiscible Biodegradable Polymers
}

\author{
Ahmed Mohamed El-Hadi \\ Department of Physics, Faculty of Applied Science, Umm Al-Qura University, Saudi Arabia
}

\begin{abstract}
Poly lactic acid (PLLA) is a promising biopolymer, obtained from polymerization of lactic acid that is derived from renewable resources through fermentation. The characteristic brittleness of PLLA is attributed to slow crystallization rates, which results in the formation of the large spherulites. Its glass temperature is relative high, above room temperature and close to $60{ }^{\circ} \mathrm{C}$, and therefore its applications are limited. The additives poly((R)-3hydroxybutyrate) (PHB), poly(vinyl acetate) (PVAc) and tributyl citrate (TBC) were used as compatibilizers in the biodegradable polymer blend of (PLLA/PPC). Results from DSC and POM analysis indicated that the blends of PLLA and PPC are immiscible. However, the blends with additives are miscible. TBC as plasticizer was added to PLLA to reduce its Tg. PVAc was used as compatibilizer to improve the miscibility between PLLA and PPC. FT-IR showed about $7 \mathrm{~cm}^{-1}$ shift in the $\mathrm{C}=\mathrm{O}$ peak in miscible blends due to physical interactions. POM experiments together with the results of DSC and WAXD showed that PHB enhances the crystallization behavior of PLLA by acting as bio nuclei and the crystallization process can occur more quickly. Consequently an increase was observed in the peak intensity in WAXD.
\end{abstract}

Keywords: Biopolymers, poly(lactic acid) PLLA, poly(propylene carbonate) PPC, blends, plasticizer, compatibilizer, Poly((R)-3-hydroxybutyrate) PHB, Poly vinyl acetate PVAc, miscibility, morphology.

\section{Introduction}

In recent years, interest has grown in biodegradable polymers derived from renewable resources, such as cellulose and its derivatives, and renewable aliphatic polyesters like PHB and PLLA, due to high oil prices, as well as the decreasing reserves of crude oil. A considerable portion of the petrochemical materials (10\% of crude oil) are used in the manufacture of plastics such polypropylene, polyethylene, polystyrene, polycarbonate and polyvinylchloride. All of these plastic materials are used widely household in food packaging; their disposal creates a big problem for the environment. Environmental awareness is growing daily, for instances against the burring the oil based polymers, therefore causing global warming and air pollution.

PLLA is a thermoplastic polyester, semi crystalline biopolymer. It is derived from renewable resources, such as corn, beet sugar, sugar cane and milk products. It is a practical alternative to conventional plastics made from petrochemicals. PLLA has been also used for biomedical applications, such as drug delivery systems, implant materials for bone fixation and surgical sutures ${ }^{[1-3]}$. However PLLA is brittle and for this reason cannot be applied in the general industrial applications, and also because its $\mathrm{Tg}$ is too high (close to $60{ }^{\circ} \mathrm{C}$ ). Therefore, it is necessary to reduce $\mathrm{Tg}$ to room temperature or lower by mixing PLLA with plasticizers.

Poly(propylene carbonate) PPC is a biodegradable aliphatic thermoplastic. It is produced from carbon dioxide and propylene oxide as a copolymer ${ }^{[4]}$ using different catalysts, such as organo-metallic compounds. $\mathrm{PPC}$ is amorphous and its glass transition temperature is $40^{\circ} \mathrm{C}$. PPC has low cost and good mechanical properties. It can be degraded to $\mathrm{H}_{2} \mathrm{O}$ and $\mathrm{CO}_{2}$ through degraded in soil-burial or in a buffer solution ${ }^{[4]}$. PPC is an amorphous polymer that can be used as a toughening agent. To solve the problem of brittleness of PLLA, physical blending is most widely used in the industry. The development of polymer blends has increased in recent years because the market needs more plastic materials. Polymer blends are defined as a mixture of two or more polymers and are divided into two types: miscible blends in which the components exist in a simple homogeneous phase and immiscible blends in which the components exist in two different phases. In miscible blends there are two or more components molecularly mixed together with no phase separation; they show one glass transition temperature. However, many polymer blends are immiscible, showing two glass transition temperatures, i.e. poor interface adhesion.

To improve interaction and enhance the compatibility between PPC and PLLA a small amount of PHB was added to the PLLA to optimize the crystallization process ${ }^{[5]}$. Tsuji et.al. has investigated that the addition of a small amount of PHB to PLLA can used as accelerating agent for improving the crystallization process in PLLA $^{[6]}$. PLLA is immiscible with $\mathrm{PHB}^{[7]}$, two phase separations was found in 50\%/50\% wt (PLLA/PHB blends $)^{[7]}$ but a small amount of PHB $(<25 \%)$ is miscible with PLLA $^{[6]}$. PVAc was used as compatibilizer to improve the miscibility between PLLA and PPC. TBC as plasticizer was added to PLLA to reduced its Tg. The PHB, PPC and PVAc have similar chemical structure like 
to PLLA. Tm of both pure PLLA and pure PHB is $174{ }^{\circ} \mathrm{C}$, $175^{\circ} \mathrm{C}$. PVAc was used as compatibilizer between PLLA and PPC to improve the phase dispersion and increase the interfacial adhesion and suppress the domains ${ }^{[8]}$. Plasticizers are low molecular weight molecules; when added to the polymer, they reduce $\mathrm{Tg}$ and $\mathrm{Tm}$. These compounds remain free between the polymer molecules, resulting in increasing the polymer chain mobility only if $\mathrm{Tg}<25^{\circ} \mathrm{C}$.

The miscibility of an immiscible blend can be improved by using the compatibilizer.

The compatibilizer have identical chemical structure, therefore allow the formation of physical interactions such as hydrogen bonding, dipole-dipole and ionic interactions, between both PLLA/PPC in the blend, so improving the miscibility of the blend. PLLA is immiscible with $\mathrm{PHB}^{[7]}$ although a small amount of PHB is miscible with PLLA resulting in a lower Tg value ${ }^{[6]}$. PLLA is also immiscible with $\mathrm{PPC}^{[8.9]}$, butadiene-styrene copolymer $(\mathrm{ABS})^{[10]}$, poly(-caprolactone) PCL $^{[11]}$, low density polyethylene blends ${ }^{[12]}$, poly(vinyl acetate-co-vinyl alcohol) ${ }^{[13]}$, poly(3-hydroxybutyrate- co-3-hydroxyvalerate) (PHBco-PHV) ${ }^{[14,15]}$, starch ${ }^{[16,17]}$ and poly(3-hydroxybutyrate-co3-hydroxyhexanoate) $\mathrm{PHB} / \mathrm{HHx}^{[18]}$, polystyrene (PS) ${ }^{[19]}$. Among the practical ways to overcome the problems of this improves immiscibility is the addition of a third polymer with certain amount miscible with the two other polymers to obtain a compatible and miscible polymeric system. For example, the addition of a suitable amount of PVAc to both PMMA and PPC makes the blends fully miscible ${ }^{[20]}$.

The addition of PVAc to the two immiscible polymers namely PLLA and $\mathrm{PPC}^{[7,9]}$ served to improve the physical properties of the blend ${ }^{[8,21]}$. However, it has been demonstrated that increasing the PVAc in its blends with the PDLA ${ }^{[22]}$ reduces the enzymatic degradation rate of PLLA. Therefore, it is not advised to increase PVAc content more than $10 \mathrm{wt} \%$. In this paper TBC, as plasticizer, was added to the PLLA, PPC and PVAc, with the purpose of decreasing its glass transition temperature and improving their miscibility. PLLA is miscible with low molecular weight plasticizers like glycerol ${ }^{[23]}$, triactine ${ }^{[24]}$ and low molecular weight citrates ${ }^{[25]}$.

The aim of this work was to investigate the newly developed blends of PLLA and PPC with additives (PHB, PVAc and TBC). The effect of additives on the compatibility, glass transition temperature, morphology and crystal structure of PLLA and PPC were characterized by various techniques such as differential scanning calorimetry (DSC), polarized optical microscopy (POM), Fourier transform infrared spectroscopy (FT-IR) and wide angle $\mathrm{x}$-ray diffraction (WAXD).

\section{Experiment}

\section{Materials}

The PLLA was white pellets with crystallinity index $(40 \%)$, glass transition temperature are in the order of $\mathrm{Tg}=60{ }^{\circ} \mathrm{C}$, and melting point as much as $\mathrm{Tm}=176^{\circ} \mathrm{C}$, and an average molecular weight of $\mathrm{M}_{\mathrm{w}}=2.2 \times 10^{5} \mathrm{~g} / \mathrm{mol}$. The PHB was a fine white powder with crystallinity index of $60 \%, \mathrm{Tg}=5^{\circ} \mathrm{C}$, melting point as much as $\mathrm{Tm}=175^{\circ} \mathrm{C}$, and average molecular weight of $\mathrm{M}_{\mathrm{w}}=2.3 \times 10^{5} \mathrm{~g} / \mathrm{mol}$. Both the PLIA and PHB were supplied by Biomer, Germany. PPC as amorphous pellets with $\mathrm{Tg}=40{ }^{\circ} \mathrm{C}$, average molecular weight $\mathrm{MW}=1.3 \times 10^{5} \mathrm{~g} \mathrm{~mol}^{-1}$, whereas PVAc amorphous pellets and with $\mathrm{Tg}=30{ }^{\circ} \mathrm{C}$, average molecular weight $\mathrm{M}_{\mathrm{w}}=0.51 \times 10^{5} \mathrm{~g} \mathrm{~mol}^{-1}$ and $\mathrm{TBC}$ were purchased from Sigma-Aldrich Chemicals Ltd.

The chemical structure of PHB, PLLA, PPC, PVAc and $\mathrm{TBC}$ is

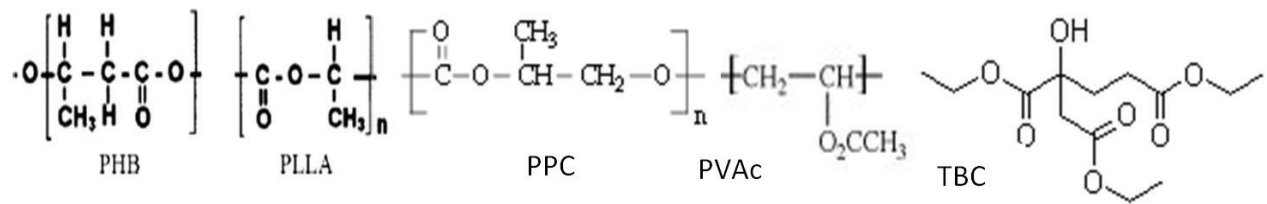

\section{Preparation of samples}

The investigated (PLLA/PPC/PHB/PVAc/TBC) blends with weight ratios: (80/20/0/0/0); (75/25/0/0/0); (70/30/0/0/0), (70/20/0/10/0); $\quad(50 / 20 / 15 / 10 / 5)$; $(45 / 20 / 15 / 10 / 10) ; \quad(35 / 25 / 15 / 10 / 15) ; \quad(25 / 30 / 15 / 10 / 20)$ were prepared by a solution method. The designations of these composites are given in Table 1. All blends were prepared by dissolving the components together in chloroform and then the solution was cast in a Petri dish to prepare the cast films. The samples, in $2 \mathrm{~mm}$ thick, were dried at $60{ }^{\circ} \mathrm{C}$ for $24 \mathrm{~h}$ to completely remove any residual solvent.

\section{Measurements}

\section{Differential scanning calorimetry (DSC)}

Thermal analysis was carried out from $-50{ }^{\circ} \mathrm{C}$ to $200{ }^{\circ} \mathrm{C}$ at heating and cooling rates of $10{ }^{\circ} \mathrm{C} \mathrm{min}-1$ using a differential scanning calorimeter (Schimadzu-DSC 50, Japan). Samples of $400 \pm 100 \mu \mathrm{g}$ were sealed in aluminum sample pans and were kept under a dry nitrogen atmosphere. The analysis of DSC curves was carried out for the second heating run data to determine the glass transition temperature $\left(\mathrm{T}_{\mathrm{g}}\right)$, the melting temperature $\left(\mathrm{T}_{\mathrm{m}}\right)$ and the cold crystallization temperature $\left(\mathrm{T}_{\mathrm{cc}}\right)$.

\section{Polarized optical microscopy (POM)}

The evolution of microstructure for all blends under investigation was examined using a POM (Nikon Eclipse E600 equipped with a hot-stage, Instec STC200, Japan). A small amount of polymer was placed between two microscope glass slides as a sandwich and inserted in the hot stage and melted at $190{ }^{\circ} \mathrm{C}$. After melting, a thin film was obtained by applied a small pressure to the top of the cover glass (the thin film was approximately $0.05-0.1 \mathrm{~mm}$ in thickness). The blend samples were heated on the 
Table 1. The samples and composition of blends.

\begin{tabular}{cccccc}
\hline Blends & \multicolumn{5}{c}{ Composition (wt \%) } \\
\cline { 2 - 6 } & PLLA & PPC & PHB & PVAc & TBC \\
\hline 1 & 80 & 20 & - & - & - \\
2 & 75 & 25 & - & - & - \\
3 & 70 & 30 & - & - & - \\
4 & 20 & 0 & 10 & 0 \\
5 & 70 & 20 & 15 & 10 & 5 \\
6 & 50 & 20 & 15 & 10 & 10 \\
7 & 45 & 25 & 15 & 10 & 15 \\
8 & 35 & 30 & 15 & 10 & 20 \\
\hline
\end{tabular}

Table 2. Thermal properties of PLLA and PPC blends and their blends with additives.

\begin{tabular}{ccccc}
\hline & \multicolumn{4}{c}{ Second heating run } \\
\hline Blends & $\mathbf{T}_{\mathrm{g} 1}\left({ }^{\circ} \mathbf{C}\right)$ & $\mathbf{T}_{\mathrm{g} 2}\left({ }^{\circ} \mathbf{C}\right)$ & $\mathbf{T}_{\mathrm{CC}}\left({ }^{\circ} \mathbf{C}\right)$ & $\mathbf{T}_{\mathbf{m}}\left({ }^{\circ} \mathbf{C}\right)$ \\
\hline PLLA ${ }^{[26]}$ & - & 60 (PLLA) & 108 & 174 \\
Blend 1 & 33 (PPC) & 53 (PLLA) & 135 & 169 \\
Blend 2 & 35 (PPC) & 52 (PLLA) & 137 & 168 \\
Blend 3 & 32 (PPC) & 50 (PLLA) & 120 & 169 \\
Blend 4 & 35 (PPC) & 51 (PLLA) & 135 & 166 \\
Blend 5 & 30 & - & 105 & 161 \\
Blend 6 & 19 & - & 90 & 162 \\
Blend 7 & 10 & - & 77 & 155 \\
Blend 8 & -14 & - & 58 & 144 \\
\hline
\end{tabular}

hot stage from room temperature to $190{ }^{\circ} \mathrm{C}$ and then kept at this temperature for $3 \mathrm{~min}$ to erase their thermal history. The samples were then cooled from $190{ }^{\circ} \mathrm{C}$ to a temperature where the growth of spherulites started and hold isothermally on $130^{\circ} \mathrm{C}$.

\section{Wide angle X-ray diffraction (WAXD)}

The crystalline phases were analyzed by wide-angle $\mathrm{x}$-ray diffraction (WAXD). The measurements were carried out using Panalytical X'pert PRO diffractometer (Netherland) with Ni-filtered $\mathrm{Cu} \mathrm{K \alpha}$-alpha radiation with wave length $\lambda=1.54178 \AA$ in the range of $2 \theta=5-35^{\circ}$ at $40 \mathrm{kV}$. The WAXD data for PLLA/PPC blends with and without additives were obtained at room temperature $\left(\sim 25^{\circ} \mathrm{C}\right)$ with a scan rate of $\left(2^{\circ}\right) 2 \theta \mathrm{min}^{-1}$. Solution cast film samples were cut into rectangular pieces $\left(4 \mathrm{~cm}^{2}\right)$ and mounted on the matrix prior to analysis.

\section{FT-IR spectroscopy}

Infrared spectra of the investigated films, which were cut into rectangular pieces of $4 \mathrm{~cm}^{2}$ area, were recorded at room temperature and in the wavenumber range $550-4000 \mathrm{~cm}^{-1}$ using a Fourier Transform FT-IR 6100 Jasco (Japan) spectrometer.

\section{Results and Discussion}

\section{Differential scanning calorimeter (DSC) analysis}

Plasticizers are additives with lower molecular weight that are added to polymeric material to reduce its brittleness. Plasticizer remain free between the polymer molecules, resulting in increasing the polymer chain mobility at room temperature. If plasticizer-polymers are compatible, all materials will form a homogeneous blend during processing. It is generally necessary that the tributyl citrate (TBC) as plasticizer and polymers have approximately the same polarity. The polar groups in TBC, PHB, PLLA, PVAc and PPC are $(\mathrm{OH}, \mathrm{C}=\mathrm{O})$, $(\mathrm{C}=\mathrm{O}, \mathrm{OH}),(\mathrm{C}=\mathrm{O}),(\mathrm{OH})$ and $(\mathrm{C}=\mathrm{O})$, respectively. The additives (PHB, PPC and PVAc) have similar chemical structure similar to PLLA, therefore some physical cross linking is occurred between PHB, PLLA, PPC, PVAc and TBC.

The value of $\mathrm{T}_{\mathrm{g}}$ depends on the mobility of the polymer chain, i.e. the more immobile the chain, the higher the value of $\mathrm{T}_{\mathrm{g}}$. It is known that neat PLLA, PPC, PVAc and PHB have glass transition temperatures of $\mathrm{cr}$. $60{ }^{\circ} \mathrm{C}^{[26]}$, $40{ }^{\circ} \mathrm{C}^{[4]}, 30^{\circ} \mathrm{C}^{[21]}$ and $5{ }^{\circ} \mathrm{C}^{[7]}$, respectively. For The glass transition temperatures $\left(\mathrm{T}_{\mathrm{g}}\right)$, cold crystallization peak temperatures $\left(\mathrm{T}_{\mathrm{cc}}\right)$ and melting peak temperatures $\left(\mathrm{T}_{\mathrm{m}}\right)$ of all PLLA/PPC blends under investigation (with and without additives) were determined from the DSC second heating runs. In previous work ${ }^{[26]}$, it was reported that the neat PLLA has used here $\mathrm{Tg}=60{ }^{\circ} \mathrm{C}, \mathrm{Tcc}=108{ }^{\circ} \mathrm{C}$, and $\mathrm{Tm}=174{ }^{\circ} \mathrm{C}$. Table 2 shows the $\mathrm{T}_{\mathrm{g}}, \mathrm{T}_{\mathrm{cc}}$, and $\mathrm{T}_{\mathrm{m}}$ of the PLLA, as well as all blends, determined by the DSC measurements. Figure 1 shows results from blends 1, 2 and 3. The blend without additives exhibited two Tg's, at about 35 and $51{ }^{\circ} \mathrm{C}$, corresponding to the $T \mathrm{~g}$ 's of PPC and PLLA, respectively. The melting temperature $\left(\mathrm{T}_{\mathrm{m}}\right)$ value of the PLLA component in the blends 1,2 and 3 was essentially unaffected and remained constant at $\left(\mathrm{T}_{\mathrm{m}}=169-170^{\circ} \mathrm{C}\right)$, this demonstrates the immiscibility of the system. Similar results were found by Wang et al. ${ }^{[9]}$. 
Figure 2 shows DSC scans of blends 4 and 5. In blend 4 the two $\mathrm{Tg}^{\prime}$ 's of PPC $\left(\mathrm{Tg}_{1}=35^{\circ} \mathrm{C}\right)$ and PLLA $\left(\mathrm{Tg}_{2}=47^{\circ} \mathrm{C}\right)$ shift toward each other with the addition of PVAc (10\%), i.e. PVAc improves the miscibility between PLLA and PPC. In case of blend 5, the addition of $5 \%$ plasticizer to PLLA, PPC, PHB and PVAc led to forming an apparent single glass transition temperature. PVAc is act as only a compatibilizer to improve the phase dispersion and increase the interfacial adhesion between PLLA and

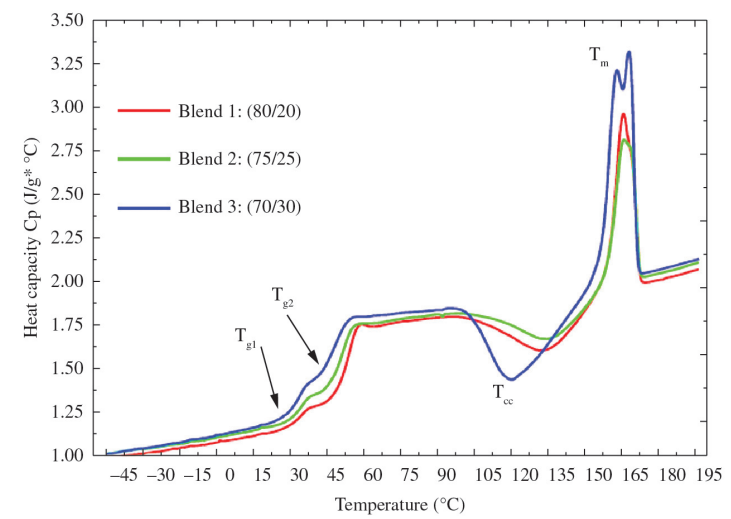

Figure 1. DSC; second heating of (PLLA/PPC) blends with different compositions.

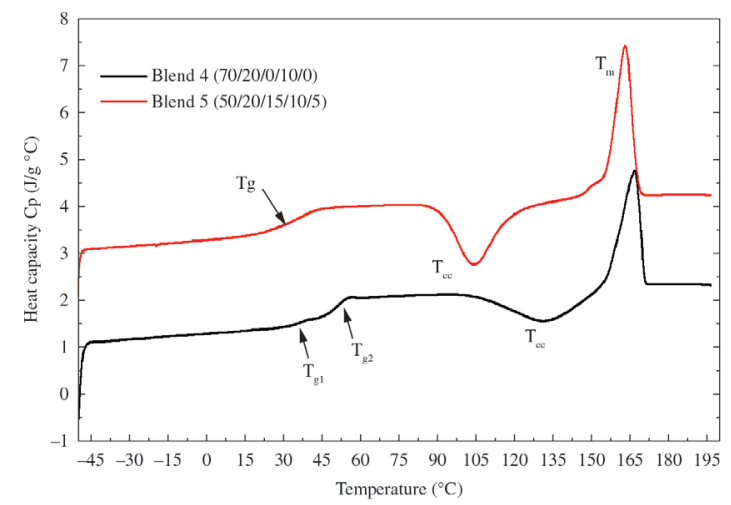

Figure 2. DSC; (a) second heating of blend 4, (b) second heating of blend 5 .

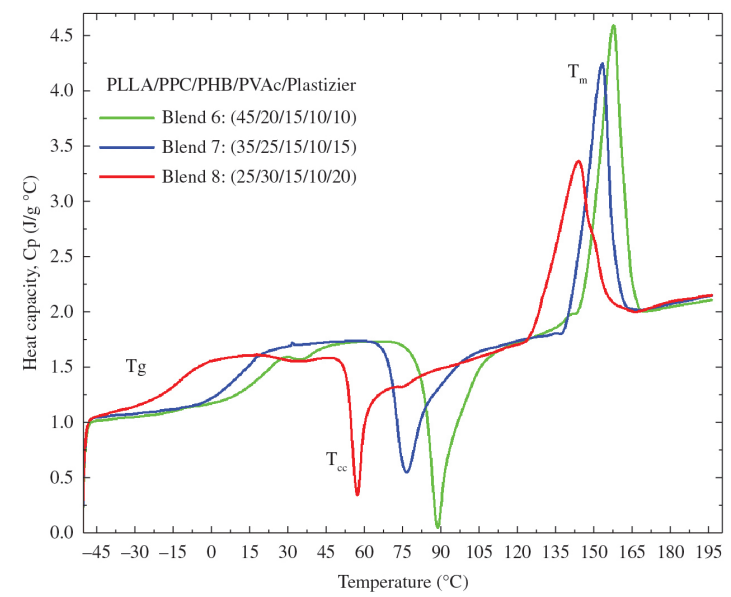

Figure 3. DSC; second heating of (PLLA/PPC/PHB/PVAc/ TBC) blends with different compositions.
PPC phases. PVAc is placed at the phase interface as a compatibilizer to reduce interfacial tension and suppress the domains. Figure 3. illustrates the second heating of blends 6,7 and 8 . The addition of plasticizer to PLLA/ $\mathrm{PPC} / \mathrm{PHB} / \mathrm{PVAc}$ reduced both $\mathrm{Tg}$ and $\mathrm{Tm}$. The respective glass transition temperatures of these blends were $19^{\circ} \mathrm{C}$, $10{ }^{\circ} \mathrm{C}$ and $-14{ }^{\circ} \mathrm{C}$. Blend 6 had one low $\mathrm{Tg}$ at $19{ }^{\circ} \mathrm{C}$ and a shoulder peak at $40{ }^{\circ} \mathrm{C}$ that was smaller but similar to all three blends 1, 2 and 3 of PLLA and PPC. However the blends 5, 7, and 8 have single glass transition temperatures at $10{ }^{\circ} \mathrm{C}$ and $-14{ }^{\circ} \mathrm{C}$ respectively. The decrease of PLLA content in blends 6,7 and 8 changes Tcc from $90{ }^{\circ} \mathrm{C}$ to $57{ }^{\circ} \mathrm{C}$. Also, increasing the additives content changes the $\mathrm{T}_{\mathrm{m}}$ from $174{ }^{\circ} \mathrm{C}$ (pure PLLA) to $144{ }^{\circ} \mathrm{C}$, i.e. the cold crystallization peak temperatures have the same trend as the melting temperatures. The reduction of $\mathrm{T}_{\mathrm{m}}$ is a typical phenomenon for miscible blends containing a crystalline polymer. Increasing the plasticizer content in blends 6,7 and 8 led to the decrease of $\mathrm{T}_{\mathrm{g}}, \mathrm{T}_{\mathrm{cc}}$ and $\mathrm{T}_{\mathrm{m}}$ as a result of the enhanced chain mobility.

\section{Morphological studies by POM}

Figures $4 \mathrm{a}, \mathrm{b}$ and $\mathrm{c}$ are shown the morphology of the spherulite of the (PLLA/PPC) blends at isothermal
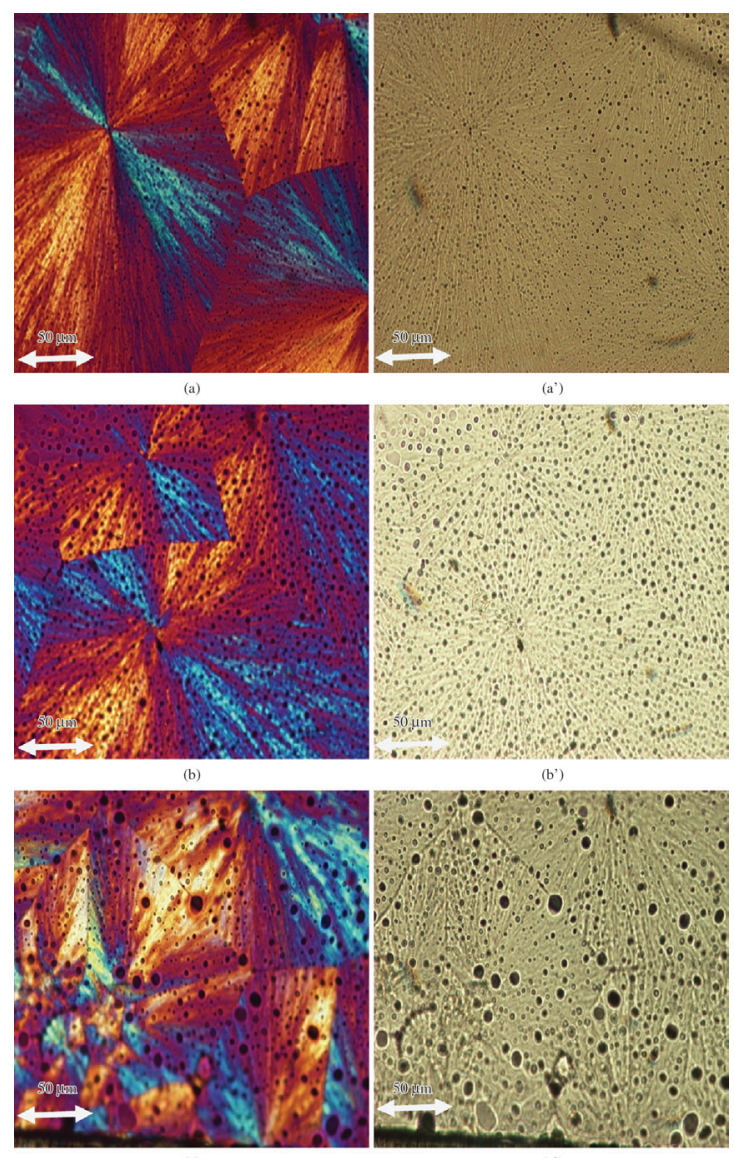

Figure 4. Spherulitic morphology of (PLLA/PPC) blends, at $120{ }^{\circ} \mathrm{C}$ crystallization temperatures: with optical polarizer (a) blend 1, (b) blend 2, (c) blend 3; without optical polarizer (a') blend 1, (b') blend 2 (c') blend 3. 
crystallization at $80{ }^{\circ} \mathrm{C}$ taken with and without polarized. It is found in blends 1,2 , and 3 phase separation in PLLA/PPC blends. It show dark spherical particles (amorphous PPC) in the morphology of spherulites. Similar results are shown by $\mathrm{POM}^{[27]}$ and $\mathrm{SEM}^{[8]}$. The size of this dark particles increased with the increasing PPC component in PLLA matrix. No separate spherical particles in PLLA matrix are observed in Figure 5a, b and c. The phase separation is disappeared completely with adding of additives (PVAc, PHB and TBC) to (PLLA/PPC) blends. Blends 6, 7 and 8 did not show phase separated domains in the morphology, i.e. stronger interfacial adhesion between PLLA, PPC and additives. The POM image was measured with optical polarizer (a), (b) and (c) while the image without optical polarizer (a'), (b') and (c'). All blends had similar, non-banded spherulite morphology, typical of pure PLLA. To demonstrate by POM that the addition of PHB improves the crystallization process of PLLA, the sample was sandwiched as a thin circular film with diameter $1.0 \mathrm{~cm}$ between two glass slides on the heated stage. As an example, Figure 6 shows the spherulitic growth of blend 7 , crystallized isothermally at $120{ }^{\circ} \mathrm{C}$ and then cooled at $80{ }^{\circ} \mathrm{C}$, optical micrographs were taken at different
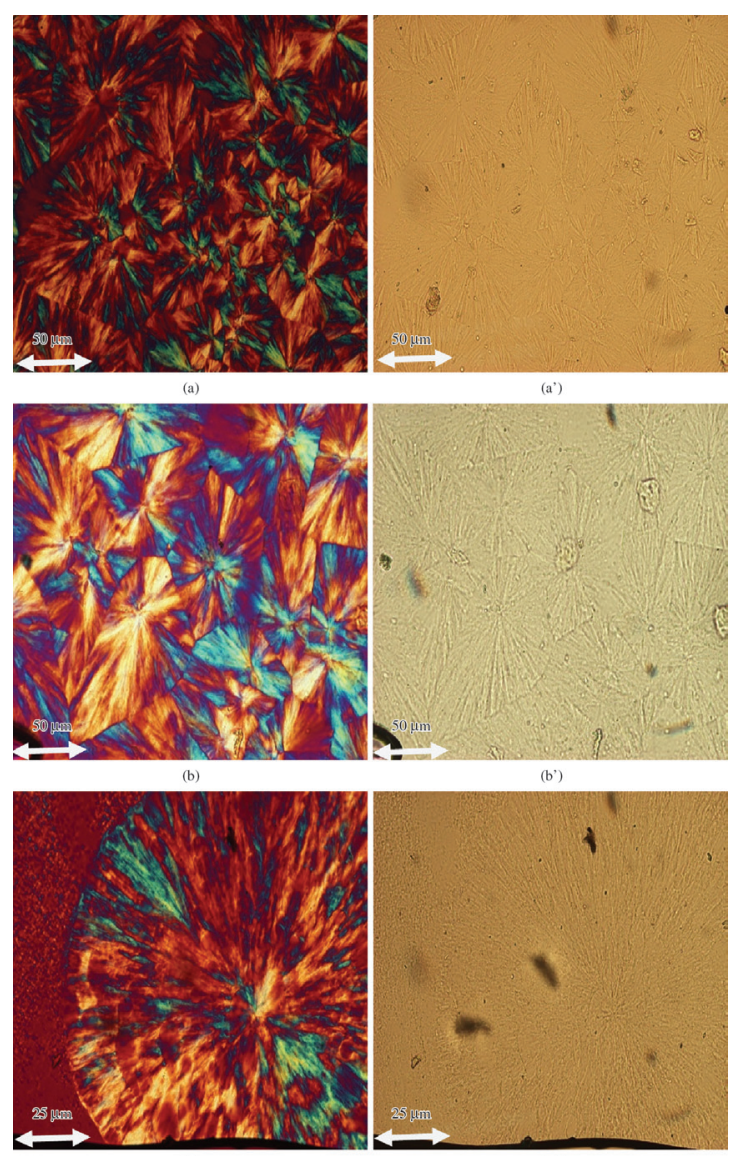

Figure 5. Spherulitic morphology of (PLLA/PPC/PHB/PVAc/ TBC) blends, at $120^{\circ} \mathrm{C}$ crystallization temperatures: with optical polarizer (a) blend 6, (b) blend 7, (c) blend 8; without optical polarizer (a') blend 6, (b') blend 7 (c') blend 8. times and at $80{ }^{\circ} \mathrm{C}$ (a) $2 \mathrm{~min}$, (b) $3 \mathrm{~min}$, (c) $5 \mathrm{~min}$, (d) $6 \mathrm{~min}$, (e) $7 \mathrm{~min}$, (f) $8 \mathrm{~min}$ with $1 / 4 \lambda$ and tint plate. It was observed by isothermal crystallizing at $120{ }^{\circ} \mathrm{C}$ that approximately 10.0 big PLLA spherulites per unit area are formed at first. These spherulites grew very slowly after 5 min with diameter up to $50 \mu \mathrm{m}$. By reducing the isothermal crystallizing to $\mathrm{Tc}=80^{\circ} \mathrm{C}$, the crystal growth rate was remarkably rapid and the nucleation density of PLLA enhanced, i.e. thousands to millions of small spherulites had been formed. Therefore the crystallization process can occur more quickly. POM proof reveals that the addition of low concentrations of PHB (15\%) as bio nucleus to PLLA can help the formation of PLLA spherulites and therefore decreases the final size of spherulites ${ }^{[28]}$. These results are consistent with the other measurements described here such as DSC, WAXD and FT-IR.

\section{FT-IR analysis}

Fourier transform infrared (FT-IR) spectroscopy was used to identify any peak shifts between the two or more polymers, therefore detecting whether the type of interaction between the materials was strong or weak. Figures 7 and 8 show the FT-IR spectra in the wavelength
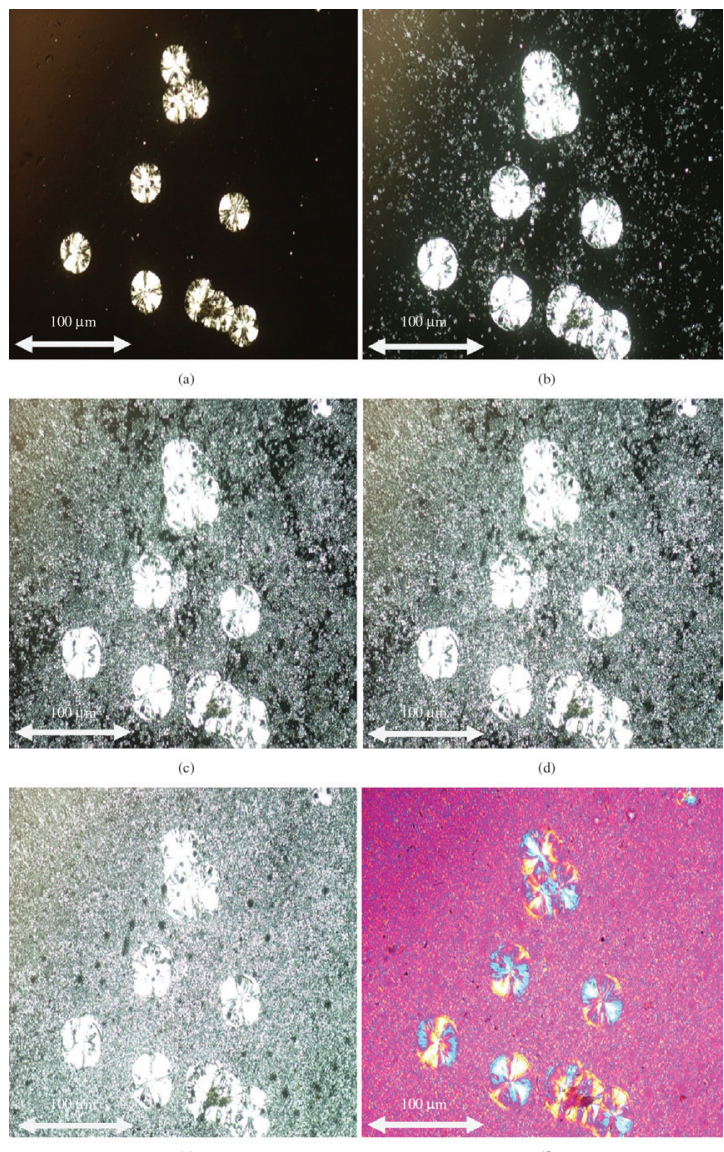

Figure 6. Polarized optical microscopy of spherulite texture of blend 7 , crystallized isothermal at 120 and then cooled at $80{ }^{\circ} \mathrm{C}$ after different time (a) 2, (b) $3 \mathrm{~min}$, (c) $5 \mathrm{~min}$, (d) $6 \mathrm{~min}$, (e) $7 \mathrm{~min}$, (f) $8 \mathrm{~min}$ with $1 / 4 \lambda$ and tint plate. 
ranges $900-1850 \mathrm{~cm}^{-1}$ and $2800-3100 \mathrm{~cm}^{-1}$ for the pure PLLA, PPC and their blends without and with additives. The band occurring in the region of $1740-1750 \mathrm{~cm}^{-1}$ corresponds to the ester carbonyl group ( $\mathrm{C}=\mathrm{O}$ group) in PLLA and PPC. The band at $1224 \mathrm{~cm}^{-1}$ is assigned to the $\mathrm{C}-\mathrm{O}-\mathrm{C}$ stretching modes of the amorphous state and the band at $1185 \mathrm{~cm}^{-1}$ is attributed to $\mathrm{C}-\mathrm{O}-\mathrm{C}$ stretching band of components the crystalline parts of PLLA. The two peaks at 1085 and $1046 \mathrm{~cm}^{-1}$ are attributed to C-O bond stretching of the C-O-C groups in PLLA. The band at $1370 \mathrm{~cm}^{-1}$ is characteristic of the crystalline state, corresponds to the stretching of $\mathrm{CH}_{3}$. The bands at 1370 and $1220 \mathrm{~cm}^{-1}$ assigned as crystalline segment of both PLLA and PHB ${ }^{[29]}$ respectively, to the coupling of $\mathrm{CH}$ deformation and $\mathrm{CH}_{3}$ symmetric deformation mode and the $\mathrm{C}-\mathrm{O}-\mathrm{C}$ stretching mode. The $\mathrm{C}-\mathrm{O}-\mathrm{C}$ group appear at $1046 \mathrm{~cm}^{-1}$ for both PLLA and PHB. These bands $1046,1085,1224$ and $1370 \mathrm{~cm}^{-1}$ are assigned

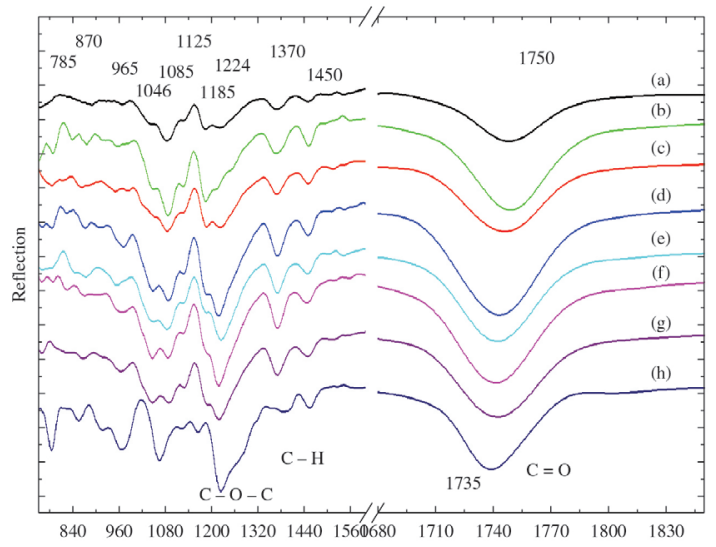

Wavenummber $\left(\mathrm{cm}^{-1}\right)$

Figure 7. FT-IR spectra of PLLA, PPC and different compositions PLLA /PPC /PHB/ PVAc/ Plasticizer) blends from its blends from 900 to $1850 \mathrm{~cm}^{-1}$, (a) $(100 / 0 / 0 / 0 / 0)$; (b) $(80 / 20 / 0 / 0 / 0)$; (c) $(75 / 25 / 0 / 0 / 0)$; (d) $(70 / 30 / 0 / 0 / 0)$; (e) $(45 / 20 / 15 / 10 / 10)$; (f) (35/25/15/10/15); (g) (25/30/15/10/20); (h) (0/100/0/0/0) w/w).

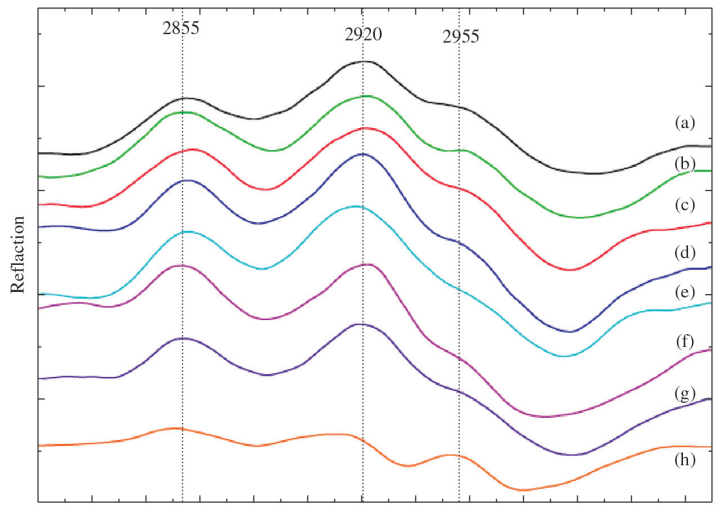

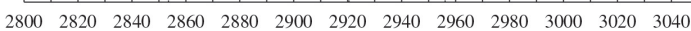
Wavenummber $\left(\mathrm{cm}^{-1}\right)$

Figure 8. FT-IR; spectra of PLLA, PPC and different compositions PLLA/PPC/PHB/ PVAc/ Plasticizer) blends from 2800 to $3050 \mathrm{~cm}^{-1}$, (a) $(100 / 0 / 0 / 0 / 0)$; (b) $(80 / 20 / 0 / 0 / 0)$; (c) $(75 / 25 / 0 / 0 / 0)$; (d) $(70 / 30 / 0 / 0 / 0)$; (e) $(45 / 20 / 15 / 10 / 10)$; (f) (35/25/15/10/15); (g) (25/30/15/10/20); (h) (0/100/0/0/0) w/w). as crystalline segment of both PLLA and $\mathrm{PHB}^{[28]}$. Its intensities are very stronger in blends than pure PLLA, i.e. these results designate that addition of small amount of PHB can help the crystallization of PLLA, because these bands associated to crystalline part in PHB. The peaks at $965,1125,1224$ and $1450 \mathrm{~cm}^{-1}$ are found in both PLLA, PPC and its blend.

Figure 8 shows that the $\mathrm{CH}_{3}$ group absorption band in the region $2800-3000 \mathrm{~cm}^{-1}$ corresponds to the asymmetrical stretching modes of the crystalline parts $\left(\mathrm{CH}_{3}\right.$ methyl group) in PHB and PLLA. There are bands for both PLLA, $\mathrm{PHB}^{[30]}$ and PPC in the C-H stretching region $\left(2955,2920\right.$ and $\left.2855 \mathrm{~cm}^{-1}\right)$. It is clear demonstrate that the intensities of the bands increase with the crystalline structure of PHB.

In many miscible polymer blends that contain carbonyl groups, there are some interactions, such as electric dipole interactions or hydrogen bonding. Consequently some peaks are shifted. In the case of our (PLLA/PPC) blends no shift in the $\mathrm{C}=\mathrm{O}$ peak occurred, which indicates that the two polymers were immiscible. However in the presence of additives as a compatibilizer in blends 6,7 and 8 , an about $10 \mathrm{~cm}^{-1}$ shift occurred by $\mathrm{C}=\mathrm{O}$ peak. This suggested that these function groups between PLLA and additives made physical interaction such as electric dipole interactions or hydrogen bond.

\section{The crystal structure by wide angle X-ray diffraction analysis}

The crystal structure of the (PLLA/PPC) blends with and without additives was studied by WAXD. PLLA crystallizes in the $\alpha$ form with an orthorhombic and the unit cell has the dimensions of $a=1.07 \mathrm{~nm}, \mathrm{~b}=0.595 \mathrm{~nm}$, and $\mathrm{c}=2.78 \mathrm{~nm}^{[31]}$. Figure 9 shows the WAXD analysis of pure PLLA and PPC, as well as their blends with and without additives. Both PPC and PLLA have a broad amorphous halo with small peak (small crystalline region) for the later at $2 \Theta=16^{\circ}$. Each investigated blend has one strong diffraction peak around $16.4^{\circ}$ corresponding to

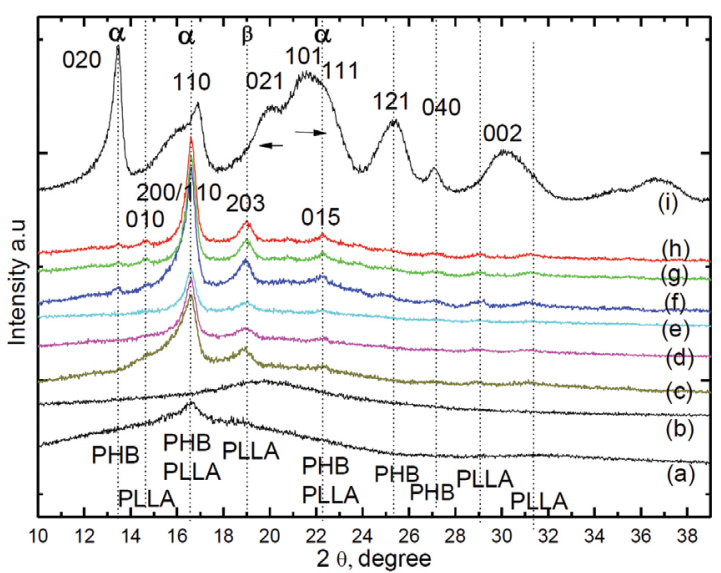

Figure 9. WAXS diffraction curves of PLLA, PPC and different compositions PLLA/PPC/PHB/PVAc/Plasticizer) blends, (a) $(100 / 0 / 0 / 0 / 0)$; (b) $(0 / 100 / 0 / 0 / 0)$ (c) $(80 / 20 / 0 / 0 / 0)$; (d) $(75 / 25 / 0 / 0 / 0)$; (e) $(70 / 30 / 0 / 0 / 0)$; (f) $(45 / 20 / 15 / 10 / 10)$; (g) (35/25/15/10/15); (h) $(25 / 30 / 15 / 10 / 20)$; (i) $(0 / 0 / 100 / 0 / 0) \mathrm{w} / \mathrm{w})$. 
(200)/(110) planes. These reflections correspond to the $\alpha$-form in PLLA. The diffraction peaks at $2 \Theta$ of $13,6^{\circ}$, $14.6^{\circ}, 16.6^{\circ}$ and $22.3^{\circ}$ are assigned to the reflections from (020), (010), (110)/(200) and (015) planes of the $\alpha$-form, respectively. The $\beta$ form is characterized by the reflection at $2 \Theta=19.1^{\circ}(203)$. The $\alpha$ - form of PHB crystal is between $(0.474-460 \mathrm{~nm})$ and the $\alpha$-form at $0.596 \mathrm{~nm}$, the $\beta$ - form has zigzag conformation, the $\beta$ - form has a hexagonal unit cell. The $\beta$-form crystal are relatively weak and its crystallinity is small in PLLA and PPC blends than PLLA and PPC blends with additives. The $\beta$ form of PLLA crystal is $0.300 \mathrm{~nm}$ and the $\alpha$-form at $0.288 \mathrm{~nm}$. Hoogsteen et al. ${ }^{[31]}$ suggested that the $\beta$ form is characterized by an orthorhombic unit cell in the 31 helical conformation. Puiggali et al. ${ }^{[32]}$ suggested that $\beta$ form has three 3 helix chains in a trigonal unit cell. Kanamoto et al. ${ }^{[33]}$ explain the molecular chains of the $\beta$-form crystals have a near hexagonal packing, because the $b / a$ is very close to $\sqrt{ } 3$. From these previous discussion we can say that, the unit cell of PHB and PLLA blends in $\beta$ - phase is near hexagonal. PLLA crystal were overlapped with the (110) reflection of the PHB crystal. The $\beta$ form crystallite appeared at $2 \theta=19^{\circ}(203)$ for both PHB and PLLA.

Addition of a small amount of PHB to PLLA can accelerate the crystallization process. New small peak appeared in blends 6, 7 and 8 correspond to PHB. The addition of small amounts of PHB to PLLA can accelerate the crystallization process. The peaks for $\alpha$ form at $16.6^{\circ}$, $22.3^{\circ}$ and $\beta$ form at $19^{\circ}$ are due to both together of PHB and PLLA. The peak at $14.6^{\circ}(010)$ plane corresponds only to PLLA and that at $13.6^{\circ}(020)$ plane only to PHB at. The intensities of both $\alpha$ - and $\beta$ form crystals of blends 6,7 and 8 were higher and the peaks sharper when compared with those of blends 1,2 and 3. The values of interplanar spacing (d) and crystal size (Lhkl) can be calculated by the following Bragg's law and Scherrer's formula

$$
\begin{aligned}
& \mathrm{d}=\mathrm{n} \lambda / 2 \sin \theta \\
& \mathrm{L}_{\mathrm{hkl}}=\mathrm{k} \lambda / \beta \cos \theta
\end{aligned}
$$

Where Lhkl is thickness of crystallite and h, k, and 1 are the Miller indices, $\mathrm{K}$ is constant dependent on crystallite shape taken $(0.94), \lambda$ is the wavelength of $\mathrm{x}$-ray (1.54 $\AA$ ), $\beta$ is the full width at half max (FWHM) or the integral breadth, $\mathrm{d}$ is the spacing between the diffracting planes and $\Theta$ is the Bragg angle. Table 3 summarizes the crystal structural parameters determined based on WAXD curves. The obtained d values for various peaks of PLLA with and without additives in the blends showed little, if any change. The $\mathrm{K}$ value corresponding to the fraction of the $\beta$-form crystal in the total crystalline phase calculated from X-ray diffractograms according to the Turner-Jones formula ${ }^{[34]}$.

$$
\mathrm{K}=\mathrm{H} \beta /\left(\mathrm{H} \alpha_{1}+\mathrm{H} \alpha_{2}+\mathrm{H} \beta\right)
$$

Where $\mathrm{H} \alpha_{1}$ andH $\alpha_{2}$ are the intensities of the peak areas (110) and (015) diffractions of the $\alpha$-form crystal, respectively, and $H \beta$ is the intensity of the (203) diffraction of $\beta$-form crystal. The $K$ values showed a small change with increasing the additives content. It was found that, while the thickness of the $\beta$ - form crystals decreased from 23.9 to $21.4 \mathrm{~nm}$ in blends 1 to 3 , it remained constant $(21.4 \mathrm{~nm})$ in the blends from 6 to 8 . Also, the thickness of the $\alpha$ - form crystals in the direction (110) decreased from 33.1 to $26.7 \mathrm{~nm}$ in the blends 1,2 and 3 while remained at a constant value of $35.7 \mathrm{~nm}$ in the blends 6 and 7 . These values were higher than that of blend 1 , which was $33.1 \mathrm{~nm}$. From these results. It is obvious that the PHB acted as heterogeneous nuclei Consequently, the peak intensity at (200/110) and (203) increases in blends 6, 7 and 8 .

\section{Conclusions}

The miscibility, morphology and crystal structure of PLLA/PPC/PHB/PVAc/TBC blends were investigated. DSC indicated that blends 1,2 and 3 of PLLA and PPC with varying composition (80/20) to (70/30) are immiscible, i.e. two $T$ g's existed, $35{ }^{\circ} \mathrm{C}$ for PPC and $51{ }^{\circ} \mathrm{C}$ for PLLA with a constant Tm at $169^{\circ} \mathrm{C}$. Blends 5,7 and 8 of are miscible in the amorphous state, i.e. a single $\mathrm{T}_{g}$ existed. The miscibility of PLLA/PPC was greatly enhanced by the addition of plasticizer, i.e. both $\mathrm{T}_{\mathrm{g}}$ and $\mathrm{T}_{\mathrm{m}}$ decreased significantly with increasing $\mathrm{TBC}$ content, $\mathrm{Tg}$ from $60{ }^{\circ} \mathrm{C}$ to $-14{ }^{\circ} \mathrm{C}$ and $\mathrm{T}_{\mathrm{m}}$ from 174 to $144{ }^{\circ} \mathrm{C}$. The nucleation density of PLLA enhanced and small spherulites had been formed by addition of PHB as bio nuclei. FT-IR indicated that the increase of additives content led to a shift of the absorption peak of $\mathrm{C}=\mathrm{O}$ due to physical interaction. WAXD showed that the intensities of the peaks at (200/110) and (203) were increased by the addition of $\mathrm{PHB}$.

\section{Acknowledgements}

The authors wish to thank Institute of Scientific Research for supporting this research through Project No. 43005001 .

\section{References}

1. Ikada, Y. \& Tsuji, H. - Macromol. Rapid. Commun., 21, p.117 (2000). http://dx.doi.org/10.1002/(SICI)15213927(20000201)21:3<117::AID-MARC117>3.0.CO;2-X

2. Amass, W.; Amass, A. \& Tighe, B. - Polym. Int., 47, p.89 (1998). http://dx.doi.org/10.1002/(SICI)10970126(1998100)47:2<89::AID-PI86>3.0.CO;2-F

3. Hartmann, M. H. High molecular weight polylactic acid polymers. In Biopolymers from renewable resources, Kaplan, D. L. (ed.), Springer, Germany, p.367 (1998). http://dx.doi.org/10.1007/978-3-662-03680-8_15

4. Inoue, S.; Koinuma, H. \& Tsuruta T. - J. Polym. Sci., Part B: Polym. Lett., 7, p.287(1969). http://dx.doi.org/10.1002/ pol.1969.110070408

5. Hu, Y.; Sato, H.; Zhang, J.; Noda, I. \& Ozaki, Y. - Polymer, 49, p.4204 (2008). http://dx.doi.org/10.1016/j. polymer.2008.07.031

6. Tsuji, H.; Sawada, M. \& Bouapao, L. - ASC applied materials interfaces, 1, p.1719(2009). 
7. El-Hadi, A. - Polym. Eng. Sci., 51, p.2191 (2011). http:// dx.doi.org/10.1002/pen.21991

8. Gao, J.; Bai, H.; Zhang, Q.; Gao, Y.; Chen, L. \& Fu, Q. - eXPRESS Polym. Lett., 6, p.860 (2012).

9. Ma, X.; Yu, J. \& Wang, N. J. - Polym. Sci. Part B: Polym. Phy., 44, p.94 (2006). http://dx.doi.org/10.1002/polb.20669

10. Li, Y. \& Shimizu, H. - Euro. Polym. J., 45, p.738 (2009) http://dx.doi.org/10.1016/j.eurpolymj.2008.12.010

11. Dell'Erba, R.; Groeninckx, G.; Maglio, G.; Malinconico, M. \& Migliozzi, A. - Polymer, p.7831(2001). http://dx.doi. org/10.1016/S0032-3861(01)00269-5

12. Kim, Y. F.; Choi, C. N.; Kim, Y. D.; Lee, K. Y. \& Lee, M. S. - Fibers Polym., 5, p.270 (2004) http://dx.doi. org/10.1007/BF02875524

13. Park, J. W. \& Im, S. S. - Polymer, 44, p.4341(2003). http:// dx.doi.org/10.1016/S0032-3861(03)00346-X

14. Peng, S. W.; An, Y. X.; Chen, C.; Fei, B.; Zhuang, Y. G. \& Dong, L. S. - J. Appl. Polym. Sci., 90, p.4054 (2003). http:// dx.doi.org/10.1002/app.12970

15. Li, J.; Lai, M. F.\& Liu, J. J. - J. Appl. Polym. Sci., 92, p.2514 (2004) http://dx.doi.org/10.1002/app.20211

16. Lu, X. L.; Du, F. G.; Ge, X. C.; Xiao, M. \& Meng, Y. Z. - J. Biomed. Mater. Res. A, 77, p.653(2006). PMid:16514604. http://dx.doi.org/10.1002/jbm.a.30664

17. Chang, L. J. - J. Polym. Environ., 8, p.33(2000). http:// dx.doi.org/10.1023/A:1010172112118

18. Furukawa, T., Sato, H., Murakami, R., Zhang, J. \& Noda, I. - Polymer, 48, p.1749 (2007). http://dx.doi.org/10.1016/j. polymer.2007.01.020

19. Mohamed, A.; Gordon, S. H. \& Biresaw, G. - J. Appl. Polym. Sci., 106, p.1689 (2007) http://dx.doi.org/10.1002/ app. 26783

20. Li, Y. \& Shimizu, H. - ACS Appl. Mater. Interfaces, 1, p.1650(2009). PMid:20355779. http://dx.doi.org/10.1021/ am900314k

21. Gajria, A. M.; Dave, V.; Gross, R. A. \& McCarthy, S. P.- Polymer, 37, p.437 (1996). http://dx.doi. org/10.1016/0032-3861(96)82913-2
22. Mahalik, J. P. \& Madras, G. J. - J. Appl. Polym. Sci., 101, p.675 (2006). http://dx.doi.org/10.1002/app.23817

23. Martin, O. \& Averous, L. - Polym, 42, p.6209 (2001) http:// dx.doi.org/10.1016/S0032-3861(01)00086-6

24. Ljungberg, N. \& Wesslen, B. - J. Appl. Polym. Sci., 86, p.1227 (2002). http://dx.doi.org/10.1002/app.11077

25. Labrecque, L. V.; Kumar, R. A.; Dave, V.; Gross, R. A. \& Mecarthy, S. P.- J. Appl. Polym. Sci., 66, p.1507 (1997). http://dx.doi.org/10.1002/(SICI)10974628(19971121)66:8<1507::AID-APP11>3.0.CO;2-0

26. El-Hadi, A. - Mater. Sci. Applic., 2, p.439 (2011).

27. Gao, M.; Ren, Z.; Yan, S.; Sun, J. \& Chen, X. - J. Phys. Chem. B, 116, p.9832 (2012). PMid:22827324. http:// dx.doi.org/10.1021/jp3041378

28. El-Hadi, A. - Polym. Eng. Sci. (2014). http//dx.doi. org/10.1002/pen.23676

29. Furukawa, T.; Sato, H.; Murakami, R.; Zhang, J.; Duan, Y.X.; Noda, I.; Ochiai, S.; \& Ozaki, Y. - Macromolecules, 38, p.6445 (2005). http://dx.doi.org/10.1021/ma0504668

30. Saito, M.; Inoue, Y. \& Yoshie, N. - Polymer 42, p.5573(2001). http://dx.doi.org/10.1016/S0032-3861(01)00011-8

31. Hoogsteen, W.; Postema, A. R.; Pennings, A. J. \& ten Brinke, G. - Macromolecules, 23, p.634 (1990). http:// dx.doi.org/10.1021/ma00204a041

32. Puiggali, J.; Ikada, Y.; Tsuji, H.; Cartier, L.; Okihara, T. \& Lotz, B. - Polymer, 41, p.8921(2000). http://dx.doi. org/10.1016/S0032-3861(00)00235-4

33. Sawai, D.; Takahashi, K.; Imamura, T.; Nakamura, K.; Kanamoto, T. \& Hyon, S. H. - J. Polym. Sci. Part B: Polym. Phys., 40, p.95(2002). http://dx.doi.org/10.1002/ polb. 10076

34. Turner-Jones, A. - Polymer, 12, p.487(1971). http://dx.doi. org/10.1016/0032-3861(71)90031-0

Received: 07/04/13

Revised: 11/13/13

Accepted: 11/18/13 